\title{
The effect of flipped learning on EFL learners' public speaking in Taiwan
}

\author{
Rachid Bezzazi \\ rbezzazi@ymail.com
}

TESOL English Department, National Taiwan Normal University, Taiwan

No. 162, Section 1, Heping East Road, Da'an District, Taipei City, Taiwan

Received: December 12, 2018; $\quad$ Accepted: February 17, 2019; $\quad$ Published: March 9, 2019

\begin{abstract}
This study investigates the effectiveness of flipped learning on English as a Foreign Language (EFL) learners' public speaking. An experimental design was implemented throughout the study, for which the researcher used convenience sampling. Seventy-nine sophomore students, from two intact English Public Speaking classes, were divided into a flipped learning group (FLG) and a conventional instruction group (CIG). This happened over a 12-week period where the focus was to investigate how a language learner's experience of flipped learning or conventional instruction affected their English public speaking. The author used quantitative and qualitative methods to collect data: a pre- and post-in-class speech and a 250-word post-treatment reflective essay. Both an independent and paired t-test were used to analyze the scores of the speeches, whereas coding was used to specify the themes that emerged from the qualitative data. The results revealed that the FLG significantly outperformed the CIG in the areas of body language and paralanguage. In addition, they did better in the areas of content and organization, and developed other skills as will be detailed later. The findings can be an impetus for EFL instructors to adopt flipped learning in an English public speaking course.
\end{abstract}

Keywords: cooperative/collaborative learning; flipped learning; teaching/ learning strategies; technology-enhanced language learning (TELL)

How to cite this paper: Bezzazi, R. (2019). The effect of flipped learning on EFL learners' public speaking in Taiwan. Journal on English as a Foreign Language, 9(1), 1-19. doi:http://dx.doi.org/10.23971/jefl.v9i1.1035 
DOI: http://dx.doi.org/10.23971/ßefl.v9i1.1035

There is a widespread claim that public speaking is the most feared concept for Americans (Allen, 2008). If this is the case with native speakers of English, then how would it be described by the learners of the language? Allen (2008) argues that people can learn public speaking, and can improve such a skill through rehearsal and constructive feedback. However, preparing and rehearsing may not be sufficient to deliver a successful presentation for quite a number of people, especially high anxiety learners: learners with fears to present publicly (Esposito, 2008). To equip students with the necessary skills to deliver an effective oral presentation, the teacher-researcher offered an English Public Speaking course to university students. The program was a new elective course at the university where the current study was conducted. It was intended for sophomores. It was the first of its kind at the university and the teacherresearcher (henceforth teacher or researcher) also designed the syllabus for the course. Before selecting a course, students were urged to read the corresponding syllabus to familiarize themselves with the course objectives and outlines. The students registering in the English Public Speaking course were required to do public speaking in class, instead of just learning about it. The course explained to students that public speaking required communication skills regardless of the language used to deliver a presentation: L1, L2, or a foreign language.

For the current study, the researcher pre-surveyed all the participants in the FLG and the CIG about their willingness to give an English public speech. The question read as follows: "How would you feel if your teacher asked you to give a presentation to the whole class next week?" A hundred percent of the students responded that they would definitely experience stage fright, known as apprehension in research. Communication apprehension refers to a kind of worry a person experiences while interacting with others in familiar or unfamiliar situations (Bodie, 2010). Horwitz (2002) declared that communication apprehension is a crucial issue that demands professional treatment. The researcher's main objective was to help students improve their English public speaking delivery. Nikitina (2012, p. 43) recommended that instructors design activities for their students to train their "mind to associate speaking in public with a positive experience." One way to facilitate such an association could be through teaching English Public Speaking through the implementation of flipped learning. Flipped Learning Newtwork (2014, p. 1) states that flipped learning is a pedagogical approach which involves two phases: the group learning space and the individual learning space. This 
combination presents students with "a dynamic, interactive learning environment where the educator guides students as they apply concepts and engage creatively in the subject matter."

To elaborate, flipped learning is a teaching approach where students complete homework outside the class first, followed by covering the related course material in class with the guidance of the teacher (Bergmann \& Sams, 2012). Research demonstrates that flipped learning can enhance students' learning experience in different disciplines and areas such as biology, computer programming, algebra, engineering, medical education, multimedia production, etc. Regarding EFL, Pudin (2017) conducted a study on students' perception of the effect of flipped learning on grammar learning. Santosa (2017) implemented flipped learning to teach EFL trainee teachers the skills to become competent in-service teachers. Flipped learning was also used to teach English idioms (ChenHsieh, Wu, \& Marek, 2017), listening (Howitt \& Pegrum, 2015), reading comprehension (Huang \& Hong, 2016), speaking (Li \& Suwanthep, 2017), pronunciation (Zhang, Du, Yuan, \& Zhang, 2016), and writing (Fauzan \& Ngabut, 2018). Flipped learning is a type of Blended Learning, which refers to an instructional combination of face-to-face and online learning to produce positive learning outcomes (Osguthorpe \& Graham, 2003). Different terms have been used to describe this new approach to learning and teaching: flipped classrooms, inverted classrooms, reversed instruction, or blended learning. Instructors implementing flipped learning design activities where students engage with learning the selected material out of class first by using the Internet, multimedia materials, or any other available tools. They then attend class to apply what they have learned. Veira, Leacock, and Warrican (2014) reported that flipped learning may indicate a fundamental change in how instructors and learners engage in the educational process through the use of technology available to them inside and outside of the class. This approach demands that students become active and take responsibility for their own learning. It is, therefore, essential for teachers to take proactive measures in addressing passiveness in students (Chen, Chen, \& Chen, 2015). Instructors are also advised to explore learners' views on the incorporation of technology into the teaching-learning process in the hope of being able to clarify any misconceptions the students may have regarding this issue.

The current study was an attempt to fill the gap in literature regarding the implementation of flipped learning in an EFL English Public Speaking course. Two research questions guided the study: 1) were there any differences between the conventional instruction group (CIG) and flipped learning group (FLG) regarding their English public speaking outcome in terms of the Total 
Score, Content-Organization Score, and Body Language-Paralanguage Score?; and 2) how did the FLG perceive the English public speaking course, which was delivered through flipped learning?

The significance of this current study is to explore the effect of flipped learning on the teaching of public speaking to EFL learners. This research endeavors to fill the gap in literature regarding this type of study. The objective of the study is to demonstrate that implementing flipped learning in teaching English public speaking is more effective than the traditional teaching method.

\section{METHOD}

This is a mixed method research which collected both quantitative and qualitative data to postulate the findings. The researcher chose to use a sample of convenience as he had two available classes of students.

The participants were 79 nineteen-year-old sophomore university students from two intact classes. They took the same elective English Public Speaking course at a private university in Zhong-Li, Taiwan. They majored in different fields: Sixty-five (82\%) students from the Bachelor of Business Administration program, six $(8 \%)$ students from the Industrial Engineering and Management program, four (5\%) students from the Arts and Design program, and four (5\%) students from the Mechanical Engineering program. The participants were roughly distributed between the two classes. They had learned English as a required subject for six years in junior and senior high school in addition to their freshman English. Based on the results of the required Mock TOEIC post-test, which they took at the end of their freshman English, the participants scored around 560 in average, ranging from 490 to 710. There were no differences in proficiency levels between the two groups $(t=.16$, $\mathrm{p}=.874$ ). TOEIC is the Test of English for International English; it is scored on a scale of 10 to 990 points. A total TOEIC score of $490-710$ is equivalent to a B1 to B2 level of proficiency on the Common European Framework of Reference (CEFR).

All participants had a two-hour English class per week, and the same researcher taught the two classes during the fall semester of the 2016-2017 academic year. The researcher has been teaching EFL to different students, from kindergarten to college, for twenty years in Taiwan. Based on an oral classsurvey, which took place in the second week of the semester, 91\% of the participants reported that they had had no experience of being involved in any activity pertaining to English public speaking in terms of attending a course or delivering a speech or an oral presentation before an audience in a formal 
manner. Regarding flipped learning, few students (5\%) had had such an experience. Therefore, engaging in English public speaking and flipped learning was new to them. The participants were formed into two groups: a flipped learning group (FLG) —a class with 40 students: 21 males and 19 females - and a conventional instruction group (CIG) - a second class with 39 students: 19 males and 20 females.

Participants were assessed on two three-minute in-class speeches/oral presentations (henceforth speech or presentation). The speeches were delivered individually; one before the treatment in Week Three and the other immediately after the treatment in Week 14. This was done to measure their development of public English speaking throughout the study. For each speech, students were given a one-week notice and were provided with a copy of the related rubric. The teacher allowed the students to select any appropriate topic of interest and to prepare their presentations before class. The teacher required each student to choose different topics for their pre- and post-speeches. The researcher designed a rubric to assess the public English speaking proficiency of the participants. It comprised eight categories assessed on a four-point scale. It was adapted from Schreiber, Paul, and Shibley's (2012) Public Speaking Competence Rubric (PSCR), Public Speaking Competency Instrument (PSCI), and Speech Evaluation Form (Schreiber et al., 2012). The participants were evaluated on (a) content (20\%), (b) organization (20\%), (c) body language: facial expressions $(10 \%)$, gestures $(10 \%)$, posture $(10 \%)$, eye contact $(10 \%)$, and $(d)$ paralanguage: speech rate $(10 \%)$ and volume $(10 \%)$. The content and organization involve the first two stages of a speech: planning and preparation. Body language and paralanguage involve the final two stages of a speech: practice and presenting. The pre-speech and the post-speech sessions were expanded by 30 minutes each to allow every participant to deliver his/her threeminute presentation. To reduce the effects of fatigue on the raters, a sevenminute break was scheduled after every ten presentations. Three raters independently scored the pre- and post-presentations: two senior ESP instructors and a TESOL PhD student. The researcher explained the grading system to the raters. The inter-reliability was $\alpha=0.83$ and $\alpha=0.87$ for the preand post-presentations, respectively.

To supplement the results of the speeches, in Week 15, the FLG participants were given an A4 sheet and required to write a 250-word posttreatment reflection essay on their experience with flipped learning. The instruction on the essay paper read as follows: "You have 30 minutes to complete this reflection essay. Please feel free to write anything about your experience in the English Public Speaking course." The participants were 
informed that the reflective essays would not make up any part of their course grade. The teacher encouraged them to write as truthfully as possible. The two senior ESP instructors individually checked and marked the forty essays. They analyzed the ideas presented in the essays and grouped them into different themes, which will be discussed in detail below. The post-treatment reflection essays were written in English.

At the first meeting with the participants, the teacher announced that there would be no print book for the course. All the course materials would be online and would include texts and videos. The researcher had carefully selected the diverse online materials to make sure they would be suitable for the participants in terms of length, difficulty level, and relevance to public speaking in English. The selected materials were all about public speaking, and the key elements leading to a successful speech. Weekly assignments for both classes were accessed from, and uploaded onto a Portal: the university Learning Management System. Students followed a weekly two-stage process. The first stage for the FLG consisted of the individual learning space. The learners were required to read online materials and watch online videos about the selected topics - the Four Ps: Planning, Preparing, Practicing, and Presenting (Week 4, 5, 6); speaking with confidence (Week 7); reducing stage freight (Week 8); knowing the audience (Week 9); the importance of body language (Week 10); the importance of paralanguage (Week 11); and speeches of famous people (Week 12-13). The participants also had to complete related follow-up activities designed by the teacher, which usually involved writing a 150-word English essay. Both groups were required to cover the following items in their weekly English essay assignment. For this assignment, students were required to write a personal reflection on the topic they had just covered, describe how they could apply the concepts they had learned from the content to their English public speaking, and suggest what else they wished to learn about the given topic.

The weekly due date for the FLG to upload the completed assignments onto Portal was one day before the associated weekly class. This gave the teacher some time to check assignments and decide how he could tailor the class to help them. The participants were asked to print out their assignment for in-class discussion. The first stage could take place anytime, anywhere, at the learners' own pace, and in their own way. Both tasks, studying the online material and completing the assignment, were to be completed outside the classroom prior to class. Emphasizing the importance of this stage, McLaughlin et al. (2016) suggested that students should be held accountable to come to class with a clear understanding of the material to be able to play their role in class 
effectively. Tucker (2012), however, warned that providing learners with educational videos alone is not enough. Teachers should design a syllabus which integrates online materials and classroom instructions into an overall approach. This first stage is the key to success of flipped learning, and instructors are to find ways to ensure that students do complete the assignment prior to class. The current study demanded the students to do follow-up activities before attending class and participate during in-class discussions. It provided maximum speaking opportunities for all group members. ArnoldGaza (2012) reported that the pre-class preparation enabled students to enter class prepared and helped them communicate with one another in a meaningful conversation. Thus, they could both reinforce their knowledge about the subject and contribute to building their peers' knowledge about the topic.

The second stage for the FLG involved the group learning space, where learners engaged in class group discussions. The participants came to class prepared and discussions were based on the three questions, which they answered in their weekly essay. Educause $(2012$, p. 1) stated that the value of flipped learning lay in turning class time into a workshop. In this environment, students have the opportunity to seek clarification about lecture content and "test their skills in applying knowledge, and interact with one another in handson activities." Following such a design, the weekly class was usually divided into 10 flexible discussion groups of four students each. Twenty minutes was allotted for group discussion, during which the researcher repeatedly informed students that it was time for them to do and practice English public speaking. The participants shared their understanding and thoughts on the topic which they had studied earlier. They were required to listen, while their teammates were speaking. They also provided one another with immediate feedback on the information and the way it was presented by each teammate. The objective of such immediate feedback was to make it as targeted as possible rather than just offering general suggestions to the whole class (Wen, 2013).

The next step demanded that one student from each group join a different team and share with them what they had discussed with their original group. This activity was called "the new group session". It usually lasted for five minutes, because only the new member had to address the new group. That group, in turn, had to provide the new member with feedback. The researcher instructed every participant to experience the new group session at least one time throughout the study. A research assistant (RA) kept a weekly record of who participated in the new group session. Once the new group session was over, the 'speakers' would return to their original groups. Then a participant from each group - there were usually 10 - either volunteered or was called 
upon to present what they had gained from both their individual learning outside class and the group learning in class. After each of the ten participants completed his her speech, classmates provided immediate feedback. This last activity occupied around 40 minutes of class time. In the end, the teacher summarized the key points of the peer-given feedback and shared them with the whole class. It is worth pointing out that the instruction, teacher-student interaction, and student-student interaction were all in English in the English Public Speaking course.

Unlike the FLG, the first stage for the CIG covered the group learning space, where the teacher lectured on public English speaking in the classroom. The instructor introduced information using PPT, showing online videos on the topic and commenting on them. The students were asked to take notes and raise questions if they had any inquiries. Each lecture usually took 40-45 minutes. Afterwards, the class was divided into groups of four and students were given 10-15 minutes for group discussions, where they shared what they had learned from the lecture. After that, one student from each team either volunteered or was called upon to present what they had gained from the lecture and group discussions, in front of the whole class. The classmates had to provide immediate feedback for each speaker, and at the end, the teacher presented a summary of the peer-given feedback to the whole class. The individual presentations occupied around 25-30 minutes of class time every week. The instructor also insisted that each participant in the CIG experience addressing the whole class at least one time throughout the study. Similarly, 10 students addressed the class every week and the RA kept a record. The second stage for the CIG was the individual learning space, outside the classroom, where the participants had to finish their weekly assignments on the topic they had covered earlier in class. The CIG was provided with the same online material that was given to the FLG, and was similarly asked to write a 150-word English essay about the topic tackling the same three questions as those for the FLG. They then uploaded their completed tasks onto Portal and made a printout for submission the following week. It is worth recalling that the FLG and CIG both followed two stages, an individual learning space, and a group learning space, with differences in the order of the stages and the medium of receiving information.

In terms of quantitative data, an independent $t$-test was run to analyze the results of the pre- and post- speeches for the FLG and CIG. A paired $t$-test was also conducted to compare the changes within each group. For the qualitative data, the reflective post-treatment essays were analyzed for content. They were checked to identify any recurring issues to identify themes. The 
researcher carefully analyzed and reviewed the essay papers. Eight themes were established regarding the FLG's perceptions towards flipped learning in the context of English public speaking.

\section{FINDINGS}

Table 1. Independent T-test of the Total Scores of the Pre- and Post-speech for FLG and CIG

\begin{tabular}{cccccccc}
\hline Individual & \multicolumn{2}{c}{ FLG } & \multicolumn{2}{c}{ CIG } & $t$ & df & sig \\
\cline { 2 - 8 } Speech & $\mathrm{m}$ & s.d. & $\mathrm{m}$ & s.d. & & & \\
\hline Pre-Speech & $\begin{array}{c}63.77 \\
(\mathrm{~N}=40)\end{array}$ & 8.55 & $\begin{array}{c}63.44 \\
(\mathrm{~N}=39)\end{array}$ & 8.50 & 0.18 & 77 & .860 \\
Post-Speech & $\begin{array}{c}71.33 \\
(\mathrm{~N}=40)\end{array}$ & 8.03 & $\begin{array}{c}67.31 \\
(\mathrm{~N}=39)\end{array}$ & 7.59 & 2.28 & 77 & $.025^{*}$ \\
\hline
\end{tabular}

-Total Score includes content, organization, body language, and paralanguage.

-Maximum score for the pre-speech and post-speech is 100 each.

$-{ }^{*} \mathrm{p}<05$

Table 1 shows the total scores of the pre- and post-speeches. The results indicate that both groups, FLG and CIG, were not different in the beginning as they started their English Public Speaking course at the same level $(t=0.18, p=$ .860). However, they both showed significant improvement in their English public speaking over the 12-week period (FLG gained more than 7 points in average, with $[t=13.5, p<.001]$ and CIG gained more than 3 points in average, with $[t=7.01, p=.001])$. In addition, the total score of the post-speech reveals a statistically significant difference between the two groups, $(t=2.28, p=.025)$, with a medium effect size (Cohen's $d=.514)$.

Table 2. Independent T-test of the $1^{\text {st }}$ Partial Scores of the Pre- and Post-speech for FLG and CIG

\begin{tabular}{|c|c|c|c|c|c|c|c|}
\hline \multirow{2}{*}{$\begin{array}{l}\text { Individual } \\
\text { Speech }\end{array}$} & \multicolumn{2}{|c|}{ FLG } & \multicolumn{2}{|c|}{ CIG } & \multirow[t]{2}{*}{$t$} & \multirow[t]{2}{*}{$\mathrm{df}$} & \multirow[t]{2}{*}{ sig } \\
\hline & $\mathrm{M}$ & s.d. & $\mathrm{m}$ & s.d. & & & \\
\hline $\begin{array}{c}\text { Pre- } \\
\text { Speech }\end{array}$ & $\begin{array}{c}27.55 \\
(\mathrm{~N}=40)\end{array}$ & 3.73 & $\begin{array}{c}27.28 \\
(\mathrm{~N}=39)\end{array}$ & 3.24 & 0.34 & 77 & .743 \\
\hline $\begin{array}{l}\text { Post- } \\
\text { Speech }\end{array}$ & $\begin{array}{c}30.15 \\
(\mathrm{~N}=40)\end{array}$ & 2.76 & $\begin{array}{c}29.49 \\
(\mathrm{~N}=39)\end{array}$ & 2.97 & 1.03 & 77 & .307 \\
\hline
\end{tabular}

$-1^{\text {st }}$ partial score includes content and organization -the planning and preparation stages-

-Maximum $1^{\text {st }}$ partial score of the pre-speech and post-speech is 40 each. $-\mathrm{p}<05$ 
Dividing the speech score into two parts-the planning and preparation parts and the practice and presentation parts-shows in detail the improvement of each group for the areas of concern. The planning and preparation parts covered both content and organization, which mainly tackled the language and structure of the speech. Table 2 shows the first Partial Scores of the pre- and post-speeches. The group comparison results did not show any significant differences before $(t=0.34, p=.743)$ and after $(t=1.03, p=.307)$ the intervention between the FLG and CIG. However, both groups demonstrated statistically significant improvements in their speech content and organization at the end of the study (FLG gained (2.6) points in average, with $[\mathrm{t}=4.75, \mathrm{p}=.001]$ and CIG gained (2.2) points in average, with $[\mathrm{t}=5.14, \mathrm{p}=.001])$.

Table 3. Independent T-test of the $2^{\text {nd }}$ Partial Scores of the Pre- and Post-speech for FLG and CIG

\begin{tabular}{|c|c|c|c|c|c|c|c|}
\hline \multirow{2}{*}{$\begin{array}{l}\text { Individual } \\
\text { Speech }\end{array}$} & \multicolumn{2}{|c|}{ FLG } & \multicolumn{2}{|c|}{$\mathrm{CIG}$} & \multirow[t]{2}{*}{$t$} & \multirow[t]{2}{*}{$\mathrm{df}$} & \multirow[t]{2}{*}{ sig } \\
\hline & $\mathrm{m}$ & s.d. & $\mathrm{m}$ & s.d. & & & \\
\hline Pre-Speech & $\begin{array}{c}35.85 \\
(\mathrm{~N}=40)\end{array}$ & 3.40 & $\begin{array}{c}36.51 \\
(\mathrm{~N}=39)\end{array}$ & 4.16 & -0.78 & 77 & .440 \\
\hline Post-Speech & $\begin{array}{c}40.70 \\
(\mathrm{~N}=40)\end{array}$ & 3.84 & $\begin{array}{c}37.69 \\
(\mathrm{~N}=39)\end{array}$ & 3.67 & 3.56 & 77 & $.001^{* *}$ \\
\hline \multicolumn{8}{|c|}{$\begin{array}{l}-2^{\text {nd }} \text { partial score includes body language \& paralanguage -the practice \& presenting } \\
\text { stages- }\end{array}$} \\
\hline
\end{tabular}

The practice and presenting parts covered body language-facial expressions, gestures, posture, eye contact-and paralanguage-speech rate and volume. Table 3 shows that the two groups started at the same level $(t=-$ $0.78, p=0.440$ ). However, at the end of the study, FLG gained (4.85) points in average, with [ $t=6.08, p=.001]$ and CIG gained (1.18) points in average, with [ $t$ $=2.08, p=.044])$. The results of the post-speech demonstrates a statistically significant difference between the scores of the FLG and the CIG $(t=3.56, p=$ .001). The FIG performed body language and paralanguage

The qualitative data from the forty post-treatment essays collected from the FLG revealed the participants' positive perception towards flipped learning. Six themes were established, namely in-class group discussions, availability of online material, English public speaking, communication skills, skill transfer, and autonomous learning. Figure 1 shows what the participants gained from and perceived most effective in flipped learning. 


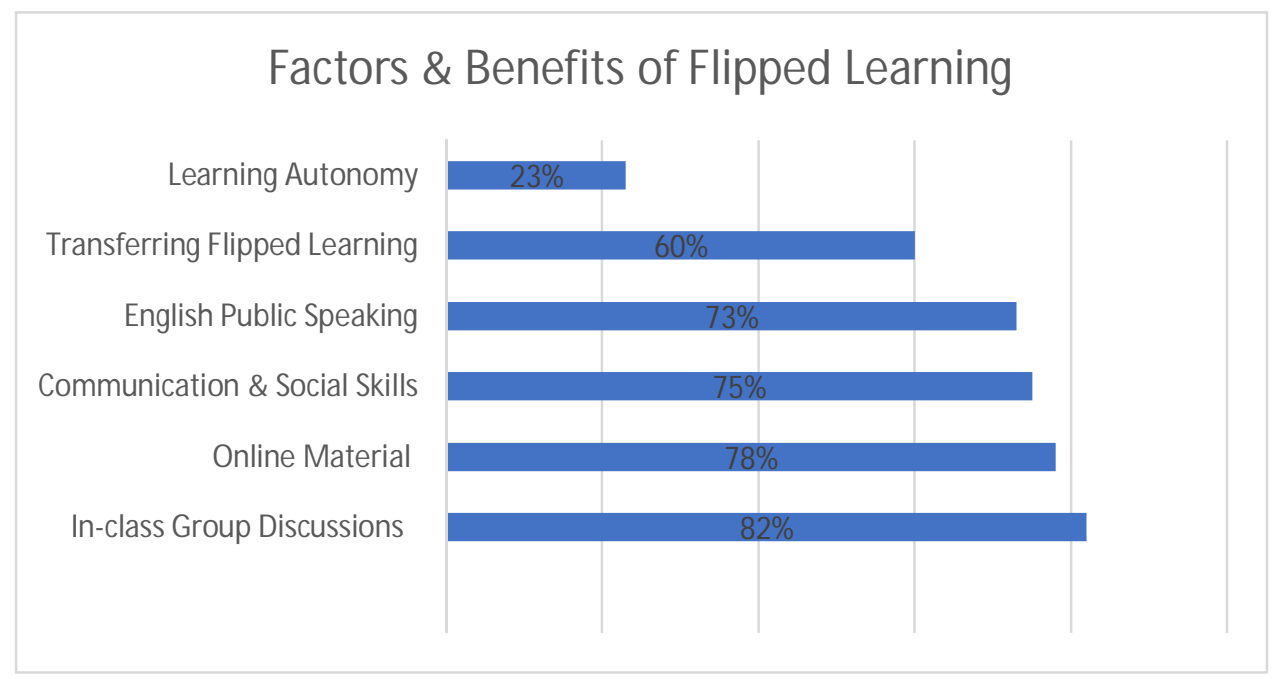

Figure 1. Students' Perceptions towards Learning English through Flipped Learning

\section{DISCUSSION}

To answer the first part of the first research question: "Were there any differences between the CIG and FLG regarding their English public speaking outcome in terms of the Total Score," the results of the post-speech demonstrated that completing homework before class was beneficial. It allowed the FIG to spend class time to share their gained knowledge about the subject, learn from, and teach one another. Crouch and Mazur (2001) declared that such cooperative activities were effective in engaging students with one another. The preparation prior to class saved the participants more class time to apply the learned concepts during the group learning space, as mentioned by Cole and Kritzer (2009). However, the CIG came to class without such preparation. Therefore, they did not save enough class time to apply what they learned from the lecture, which occupied around 45 minutes. They seemed to focus more on the teacher's lecture in class. Outside class, they had to individually complete the weekly 150-word essay.

To answer the second part of the first Research Question: "Were there any differences between the CIG and FLG regarding their English public speaking outcome in terms of the Content-Organization Score," the first partial results of the post-speech, as shown above, did not show any significant difference between the two groups. Nevertheless, taking the English public speaking course was effective to some extent in developing learners' skills related to content and organization, regardless of the teaching medium used. The results echoed Carswell, Thomas, and Petre's (2000) findings when they 
declared that they did not find any differences between the performance of the Internet students and that of the conventional participants.

To answer the third part of the first Research Question: "Were there any differences between the CIG and FLG regarding their English public speaking outcome in terms of the Body Language-Paralanguage Score," the second partial results of the post-speech demonstrated that, as shown in Table 3 above, there was a statistically significant difference between the FLG and CIG. The FLG scored (3.01) points higher. This difference in the post-speech regarding body language and paralanguage suggests that training students in English public speaking through flipped learning is more effective than the conventional instruction mode, as used in this study. In this section, the FLG demonstrated better skills than the CIG to manage their facial expressions, to express their emotion through posture and gestures, to maintain eye contact, and to control their speech rate and volume. The weekly study and preparation the FLG did in their individual learning space prior to class seemed to have saved them more class time. This finding agrees with other studies (Bergmann \& Sams, 2012; Educause, 2012, Hung, 2017). Instead of sitting and listening to the teacher's instruction, the FLG used this additional time to focus on and practice the non-linguistic features involved in delivering an English public speech.

Moreover, the pre-class preparation helped the FLG participants develop learning strategies to synthesize and analyze information. This resulted in them gaining the skills to deal with complex challenges. Performing preparatory work prior to class increased their willingness to communicate, because they had some knowledge to share and questions to ask. Flipped learning, as used in this study, provided the learners with opportunities for meaningful interactions in English. The students developed the skills to evaluate their classmates and scaffold one another. They also exchanged targeted feedback, as recommended by ChenHsieh et al. (2017). The participants entered the class with the knowledge of how to plan, prepare, practice, and present their speeches. In class, they collaboratively elaborated on the learning materials. As a result, the FLG learning outcome has increased significantly as shown in Tables 1 and 3.

To answer the second Research Question: "How did the FLG perceive the English public speaking course through flipped learning," the analysis of the reflection essays indicated that the FLG members were satisfied with the course. They wrote about the in-class small group discussions, availability of the selected online material, English public speaking, communication and social skills, flipped learning transfer, and autonomy learning. 
In support of Marlowe (2012), the in-class small group discussions did create a place for the participants to learn skills with a low level of stress. The analysis of the essays demonstrated that students experienced lower anxiety in their English Public Speaking course. Thirty-four students (84\%) reported that they had become less shy, braver, and more comfortable with sharing their knowledge and asking for clarification. The in-class small group discussions helped around thirty-two participants (80\%) to positively change their learning beliefs. The students declared that the weekly discussions provided an environment for them to become both students and teachers at the same time. Every week, the participants had an interactive class in terms of teaching and learning from one another. In this vein, Educause (2012, p. 1) claimed that flipped learning is an opportunity for students to take more responsibility for their learning. One student explained that "In the beginning, I did not like this flipped learning because it was stressful," but around the end of the treatment they declared that "Now, I feel very lucky to have had this kind of class." The students expressed that at the beginning of the semester, they were overloaded with the before-class preparation and were not used to such an interactive class. However, through time they positively changed their attitude towards the flipped learning approach. The students reported to have discovered that they were successfully doing public English speaking in class, instead of just learning about it. The activities the teacher designed for both in and outside of class, as used in this study, proved effective in helping students meet the objectives of the course: giving a successful public speech in English.

The second most positive feedback on flipped learning was the availability of the selected online material. Thirty-one participants (78\%) indicated that the weekly online materials the teacher uploaded onto Portal prior to class helped them enter the class ready to contribute. One student commented that "I believe it is a useful way to prepare for class beforehand. It helped me learn better, because I felt ready to participate in class and was not afraid of making mistakes." This finding was similar to the results reported by ChenHsieh et al. (2017, p. 14) where they stated that the online material "had the highest mean score among all the ... items, indicating that the participants recognized the usefulness of the materials created by the instructors."

Flipped learning, as used in this study, was effective in boosting the participants' English public speaking. Twenty-nine students (73\%) expressed that flipped learning helped them reduce communication apprehension, which they were suffering from before the treatment. They confidently declared they were ready to deliver an English public speech at any time. They wrote that they had gained the skills to convey the intended message to their audience. 
One student claimed that "I have learned how to do that. Follow the four 'P's [planning, preparing, practicing, presenting]. Speak loud, clearly, and slowly. And don't forget to have eye contact with your audience." Furthermore, as shown in Figure 1, flipped learning was beneficial to the participants in other areas.

Thirty-one participants (78\%) reported that flipped learning was effective in helping them learn how to communicate with group members in terms of listening to one another, taking turns, negotiating, and making friends. The participants stated that they learned how to listen carefully to their teammates. They let them finish their ideas first, and then shared with them what they knew. In addition, one participant stated that during the weekly class group discussion "...we sit and study with different students. I have made many friends now and I feel I can talk to different people so easily." These reflections confirm the findings of earlier studies that group study increases communication skills among students (Gillies \& Boyle, 2010; Shih, 2011).

Twenty-four students $(60 \%)$ reported that they were ready to transfer their experience in the English public speaking through flipped learning to studying other subjects, a view supported by Enfield (2013). Most of these students claimed they had already recommended flipped learning to other schoolmates and some of their professors. One student wrote "Thank you, teacher, for showing us this way of learning [flipped learning]. I am sure I can use it to learn and improve my Calculus."

Interestingly, nine participants (23\%) claimed that English public speaking through flipped learning enhanced their learner autonomy. These 'autonomous' learners expressed their gratitude to the teacher for training them to be responsible for their studies. One student declared that "After this course, I will keep using flipped learning to learn new things and I am planning to join an English Café in Taipei where people can meet once a week and share something in English with the club members." Other participants reported that they kept watching TED Talks to further develop their public speaking. They also started looking for opportunities to participate in public events such as a PPT Presentation Contest, a Story-telling Contest, a Reading Contest, or a Speech Contest organized at their university or other places off-campus. In this regard, Amiryousefi (2017, p. 10) claimed that flipped learning can "enhance students' self-study skills and hence their autonomy."

As used in this study, the cooperation between the teacher and students to set a classroom culture from the very beginning of the course and adhere to it facilitated the transfer from conventional instruction to flipped learning. For 
example, studying and completing homework prior to class. The instructor did not double lecture on the course content, for example, English Public Speaking, in the current study. He observed students, circulated among them, listened to their group discussions, joined the discussions, asked questions, gave feedback, and cleared up any misconceptions students might have had. The participants were required to come to class prepared, and were taught about the value of what they were doing. They found themselves embracing a new role regarding their studies. The teacher raised the students' awareness that he was not the sole knowledge provider any more. Students had to share the responsibility and take some charge of their learning (White et al., 2015). This awareness urged them to spend enough time seriously studying the materials beforehand. It is worth noting that the weekly per-class activities contained an item asking the FLG participants about the amount of time spent on their preparation. The average time was two hours 40 minutes. This amount of time spent outside the classroom resulted in an increased practice time, which in turn helped students produce better results.

\section{CONCLUSION}

This study indicates that it is possible to implement flipped learning to enhance EFL learners' public speaking. Flipped learning, as used in this study, was shown to be more effective than conventional instruction. It helped the students to deliver better English speeches and oral presentations, in terms of body language and paralanguage. The researcher argues here that EFL instructors should make an effort to get out of their comfort zone and learn how to incorporate technology in their teaching. This could help improve their students' English performance: English public speaking, for example. Implementing flipped learning has now become easier thanks to the existence of valuable ready-made online materials, easy access to the Internet, the increasing affordability of technological devices: laptop, tablets, smartphones, and the fact that EFL learners are Internet residents. Though the results presented here are positive, some limitations were observed. The focus of the current English Public Speaking course was to develop the practical skills of English public speaking. To reduce the workload for students, the teacher decided not to include the areas of grammar, structure, and originality in the evaluation. Moreover, the treatment period was only 12 weeks. Future research could replicate the study with a more advanced level of participants and add the structure, grammar, and originality components to the evaluation of the learners' speeches. Future studies may also consider the gender variable in exploring the effect of flipped learning on the English public speaking of EFL learners. Finally, since two instructional designs were adopted for comparison, 
it is suggested that future research compare students' perception about the two treatments they received.

\section{REFERENCES}

Allen, D. (2008). Teaching. NEWSLETTER, 18(1).1-8.

Amiryousefi, M. (2017). The incorporation of flipped learning into conventional classes to enhance EFL learners' L2 speaking, L2 listening, and engagement. Innovation in Language Learning and Teaching, 1-15. https://doi.org/10.1080/17501229.2017.1394307

Arnold-Garza, S. (2014). The flipped classroom teaching model and its use for information literacy instruction. Communications in Information Literacy, 8(1), 7-22. https://doi.org/10.15760/comminfolit.2014.8.1.161

Bergmann, J., \& Sams, A. (2012). Flip your classroom: Reach every student in every class everyday. Washingtom, DC: ISTE; and Alexandria, VA: ASCD.

Bodie, G. D. (2010). A racing heart, rattling knees, and ruminative thoughts: Defining, explaining, and treating public speaking anxiety. Communication $\quad$ Education, 59(1), 70-105. https://doi.org/10.1080/03634520903443849

Carswell, L., Thomas, P., Petre, M., Price, B., \& Richards, M. (2000). Distance education via the Internet: The student experience. British Journal of Educational Technology,31(1), 29-46. https://doi.org/10.1111/14678535.00133

Chen, L., Chen, T. L., \& Chen, N. S. (2015). Students' perspectives of using cooperative learning in a flipped statistics classroom. Australasian Journal of Educational Technology, 31(6), 621-640. https://doi.org/10.14742/ajet.1876

ChenHsieh, J., Wu, W. C., \& Marek, W. M. (2017). Using the flipped classroom to enhance EFL learning. Computer Assisted Language Learning, 30(1-2), 121. https://doi.org/10.1080/09588221.2015.1111910

Cole, J. E., \& Kritzer, J. B. (2009). Strategies for success: Teaching an online course. Rural Special Education Quarterly, 28(4), 36-40. https: //doi.org/10.1177/875687050902800406

Crouch, C. H., \& Mazur, E. (2001). Peer instruction: Ten years of experience and results. American Journal of Physics, 69(9), 970-977. https://doi.org/10.1119/1.1374249 
Educause, C. (2012). Things you should know about flipped classrooms. Retrieved from https://ibrary.educause.edu/ /media/files/ibrary/2012/2/eli7081-pdf.pdf

Enfield, J. (2013). Looking at the impact of the flipped classroom model of instruction on undergraduate multimedia students at CSUN. TechTrends, 57(6), 14-27. https://doi.org/10.1007/s11528-013-06981

Esposito, J. (2008). In the spotlight: Overcome your fear of public speaking and performing. Capstone Publishing, Chichester.

Fauzan, A., \& Ngabut, M. N. (2018). EFL students' perception on flipped learning in writing class. Journal on English as a Foreign Language, 8(2), 115-129. http://dx.doi.org/10.23971/jefl.v8i2.792

Flipped Learning Network. (2014). The four pillars of F-L-I-P. Retrieved from http://classes.mst.edu/edtech/ГLT2014/BCH120/AbkemeierFLIP_handout _FNLWeb.pdf

Gillies, R. M., \& Boyle, M. (2010). Teachers' reflections on cooperative learning: Issues in implementation. Teaching and Teacher Education, 26(4), 933-940. https://doi.org/10.1016/.tate.2009.10.034

Horwitz, B. (2002). Communication apprehension: Origins and management. New York, New York: Cengage Learning.

Howitt, C., \& Pegrum, M. (2015). Implementing a flipped classroom approach in postgraduate education: An unexpected journey into pedagogical redesign. Australasian Journal of Educational Technology, 31(4), 458-469. https://doi.org/10.14742/ajet.2439

Huang, Y. N., \& Hong, Z. R. (2016). The effects of a flipped English classroom intervention on students' information and communication technology and English reading comprehension. Educational Technology Research and Development, 64(2), 175-193. https://doi.org/10.1007/\$11423-015-9412-7

Hung, H. T. (2017). The integration of a student response system in flipped classrooms. Language Learning \& Technology, 21(1), 16-27.

Li, S., \& Suwanthep, J. (2017). Integration of flipped classroom model for EFL speaking. International Journal of Learning and Teaching, 3(2), 118-123. https://doi.org/10.18178/jilt.3.2.118-123 
Marlowe, C. A. (2012). The effect of the flipped classroom on student achievement and stress. (Unpublished master's thesis). Bozeman: Montana State University. Retrieved from https://scholarworks.montana.edu/xmlui bitstream/handle/1/1790/Marlo weC0812.pdf?sequence=1\&isAllowed=yhttps://doi.org/10.1111亿.14682958.1977.tb00599.x

McLaughlin, J. E., White, P. J., Khanova, J., \& Yuriev, E. (2016). Flipped classroom implementation: A case report of two higher education institutions in the United States and Australia. Computers in the Schools, 33(1), 24-37. https://doi.org/10.1080/07380569.2016.1137734

Nikitina, A. (2012). Successful public speaking. Bookboon. Retrieved from http://earnexcollege.co.za/wp-content/uploads/2014/04/Successfulpublic-speaking.pdf

Osguthorpe, R. T., \& Graham, C. R. (2003). Blended learning systems: Definitions and directions. Quarterly Review of Distance Education, 4(3), 227-234.

Pudin, C. S. J., (2017). Exploring a flipped learning approach in teaching grammar for ESL students. Indonesian Journal of English Language Teaching and Applied Linguistics, 2(1), 2017. http://dx.doi.org/10.21093/ijeltal.v2i1.47

Santosa, M. H. (2017). Learning approaches of Indonesian EFL Gen Z students in a Flipped Learning context. Journal on English as a Foreign Language, 7(2), 183-208. http://dx.doi.org/10.23971/jefl.v7i2.689

Schreiber, L. M., Paul, G. D., \& Shibley, L. R. (2012). The development and test of the public speaking competence rubric. Communication Education, 61(3), 205-233. https://doi.org/10.1080/03634523.2012.670709

Shih, R. C. (2011). Can Web 2.0 technology assist college students in learning English writing? Integrating Facebook and peer assessment with blended learning. Australasian Journal of Educational Technology, 27(Special issue, 5), 829- 845. https://doi.org/10.14742/ajet.934

Tucker, B. (2012). The flipped classroom. Education Next, 12(1), 82-83. Retrieved from https://search.proquest.com/docview/1237826701?pqorigsite $=$ gscholar

Veira, A. K., Leacock, C. J., \& Warrican, S. J. (2014). Learning outside the walls of the classroom: Engaging the digital natives. Australasian Journal of Educational Technology, 30(2), 227-244. https://doi.org/10.14742/ajet.349 
Wen, Q. (2013). Application of the output-driven hypothesis in college English teaching; Reflections and suggestions. Foreign Language World, 6(5), 14-22.

White, P. J., Larson, I., Styles, K., Yuriev, E., Evans, D. R., Short, J. L., \& Eise, N. (2015). Using active learning strategies to shift student attitudes and behaviours about learning and teaching in a research intensive educational context. Pharmacy Education, 15(1), 162-172.

Zhang, H., Du, X., Yuan, X., \& Zhang, L. (2016). The effectiveness of the flipped classroom mode on the English pronunciation course. Creative Education, 7(09), 1340-1346. https://doi.org/10.4236/ce.2016.79139

\section{Author's Brief CV}

Rachid Bezzazi is a language instructor at HCT in the UAE and a PhD applicant in TESOL at National Taiwan Normal University, Taiwan. His research interests include Monitored Extensive Reading, Cooperative Learning, flipped learning, and Language Policy and Planning (LPP). 